\title{
On the translation-proper of toponyms in Romanian translations at the beginning of the $19^{\text {th }}$ century ${ }^{\dagger}$
}

\author{
Dinu Moscal ${ }^{*}$ \\ "A. Philippide" Institute of Romanian Philology, Str. Th. Codrescu 2, 700481 Iași, Romania
}

\section{Article info}

History:

Received July 19, 2018

Accepted August 20, 2018

Published October 7, 2018

Key words:

proper name

toponym

translation

Romanian language

the $19^{\text {th }}$ century

\begin{abstract}
The translation of certain toponyms that had not yet been assimilated to the Romanian language at the beginning of the 19th century represented a real challenge for translators at that time. A first aspect to be considered here is the linguistic status as proper names and the possible translation options that could not be correlated to any tradition. A second aspect is the precarious stage of Romanian geographical terminology, reflected by the terminological variation for the same concept and the lack of semantic affinity, either real or related to the actual terminology. This article addresses mainly the first aspect mentioned above. The issues addressed are as follows: a concise presentation of the concept of proper names translation, the distinction between untranslatable and translatable or partially translatable proper names, the factors motivating the option of translating or not the translatable terms from a toponymic collocation. Our corpus reflects the incipient stage of the translation of translatable or partially translatable toponyms in Romanian, a stage in which the translator is free to decide upon translatability. Compared to the actual norm, the different choices from one translator to another or even those opted for by the same translatorespecially the option of not translating toponyms that are nowadays translated in most languages - reveal the lack of importance of linguistic meaning (that is the lexical meaning of the etymon) of the proper name as far as its functioning was concerned, as well as the role of this non-functionality in identifying the linguistic status of a proper name.
\end{abstract}

\section{Introduction}

The translation of proper names is as complex as the status of the proper name as a linguistic sign, being characterized by the same heterogeneity concerning the perspectives and approach methods. The difficulties in linguistically defining the proper name, of which the most significant seems to be the issue of its semanticity, render the results of the analysis of proper names in translation less convergent at a general level. Vaxelaire's statement (2005, p. 63) about the linguistic status of proper names can be thus considered valid as far as the translation of proper names is concerned: "Il est courant de lire tout et son contraire sur le nom propre, on glose beaucoup à son sujet sans pouvoir pour autant prendre le temps de définir ce qu'il est exactement".

The eclectic approach of the strategies implying the transfer of the proper name from one language into another is favoured by its lack of clear identity as a linguistic entity, mainly with regard to its content: "the only words one does use as names in the logical sense are words like «this» or «that»" (Gardiner, 1957, p. 59, an idea also shared by Kuryłowicz, 1980, p. 6); "il peut y avoir des sous-catégories fonctionnelles, comme le nom propre à l'intérieur des pronoms-substantifs" (Hjelmslev, 1971, p. 207); "le nom propre est [...] fondamentalement un référent" (Clarinval, 1967, p. 34); "en effet, le nom propre est un nom, mais

${ }^{\dagger}$ This paper was presented at the symposium “Toponymy between history, geography and linguistics”, Iași, May $10^{\text {th }}, 2018$.

*Email address: dinu.moscal@gmail.com. 
son fonctionnement morpho-syntaxique, sémantique et pragmatique le rapproche des déictiques, des pronoms personnels par exemple" (Molino, 1982, p. 19). The lack of a semantic content or, according to the terminology used by logicians, the lack of 'meaning' concords with the viewpoint of some onomasticians with regard to the translatability of proper names, e.g.: "ne se traduisent presque jamais" (Mańczak, 1968, p. 207), "they are untranslatable" (Algeo, 1973, p. 63).

If we are to consider that the functioning of a proper name is not based on the signification relationship (as in the case of common names), but on the denomination relationship (equivalent with the designation relationship at the common names level), and that the signification relationship is only activated at a metalanguage level (the etymological approach, be it scientific or not), knowing the meaning of a proper name is not relevant for its functioning. Emphasizing the denominative function of the proper name, Kleiber (1981, p. 503) asserts that "toute modification aboutit, non à une traduction d'un nom propre, mais à un nouveau nom propre". Thus, from a functional perspective, the translation of proper names is rather denied than analyzed. It is nevertheless evident that proper names do not remain unaltered following their transition from one language into the other (one possible option being the translation-proper); this led to various analyses of the strategies used in translation. The lexical meaning is also translated in the case of proper names, yet it does not hold the same position within the proper name as it holds within the common name. Moreover, the lexical meaning does not play a part in the functioning of the proper name, but it is rather an under-layer element. In the case of proper names, the lexical meaning is similar to the etymologic meaning at the lexis level.

The proper names Coasta de Fildeș, Ivory Coast, Elfenbeinküste, Costa de Marfil or Marele Lac Sărat, Grad Lac Salée, Großer Salzsee, El Gran Lago Salado translate the proper names Côte d'Ivoire and The Great Salt Lake. However, some proper names cannot be translated, while others can. Of the last category, some are translated, while others are not. This evidence shows the real issue about the translation of proper names: this is not whether they are translated or not, but why some of the translatable names are translated while others are not. Expressing differently, before approaching the problem of their translation, one should approach their translatability. An intermediate step would be to determine why some translatable proper names are translated (see the examples above), while others are not (Salt Lake City, Rio Grande, Mont Blanc, etc.).

Another topic concerning the translation of proper names is the non-differentiated treatment at a general level of the titles and proper names (which can function as titles or parts of titles). Thus, Ansichten eines Clowns is a title that does not include any proper name, North Atlantic Treaty Organization is a title that comprises a proper name (the toponym Atlantic), while Anna Karenina is a title consisting of an untranslatable proper name; titles can be translated entirely (as in the first example), partially (as in the second example) or they cannot be translated at all (as in the third example). On the other hand, some denominative collocations (compound proper names) are partially translated, as in the following examples: Lat. Mare Mediterraneum - Fr. Mer Méditerranée, Rom. Marea Mediterană, Engl. Mediterarranean Sea (but Germ. Mittelländische Meer or Mittelmeer); Engl. United States of America - Fr. Étas-Unis d'Amérique, Rom. Statele Unite ale Americii, etc. Accordingly, a typology of the translation of proper names, including toponyms, should consider the criterion of translatability and discern, first of all, between the properties that render a proper name translatable or untranslatable and then between the properties that make translatable (or partially translatable) proper names be translated, partially translated or untranslated.

\section{Translation-proper}

Most translation theories agree that, in the case of proper names, the term translation has a double use: it is used as a generic term, comprising any strategy of rendering a proper name from one language into another, and as a specific term, comprising only those translation strategies that carry semantic implications (cf. Moya, 2001; Grass, 2002; Ballard, 2011). In the first case, the translation of proper names includes formal 
strategies (graphic, phonetic and morphologic adaptation), as well as borrowings; the proper name is basically preserved in the form it has in the source language (for examples concerning the $19^{\text {th }}$ century Romanian, see Gînsac et al., 2017, p. 61-66).

The strategies associated with the generic term translation vary from one author to another; see, for example, the typology of Grass (2002, p. 115-122): calque (Strait of Dover = Strasse von Dover = Pas de Calais), literal translation (NATO North Atlantic Treaty Organization= OTAN Organisation du Traité de l'Atlantique Nord = Nordatlantikpakt-Organisation), transposition (das Vorparlament $=$ le Parlament préparatoire), modulation ([Sieg bei] Königgrätz $=$ [Défaite de] Sadowa), adaptation (Ansichten eines Clowns $($ H. Böll $) \approx$ La Grimace), explanatory translation (Studienstiftung des Deutschen Volkes - "organisation allemande qui accorde des bourses aux meilleurs étudiants allemands"), full equivalence (Versailler Vertrag - Traité de Versailles). It is evident that this typology is connected to the general translation theories. Grass indicates the sources (Malblanc, 1968 and Vinay \& Darbelnet, 1958) and the transfer of the translation strategies typology: "Malgré leur âge, ces ouvrages proposent une terminologie simple et toujours utilisée" (Grass, 2002, p. 114). Other scholars (Ballard, 2011; Moya, 2001), who propose such typologies, still fail to contribute in a significant manner to the field.

The translation-proper of the proper names resides in the translation of the etymological meaning of the semantically transparent constitutive term(s). Even though the etymological meaning usually proves the designation relationship the creation of the denominative collocation is based upon, this meaning only confirms the „rightful denomination” of a particular reality, without playing a part in identifying it, although this last aspect represents the distinctive trait of proper names. For example, if we should come across the Romanian translation Orașul nou [New City] (for any of the toponyms below), the etymological meaning refers beyond doubt to the name of a human settlement (a city), indicating only the onomastic category and being thus less clear about the designation relationship (which city). Yet, the Russ. Novgorod, Fr. Villeneuve / Neuville, Germ. Neustadt, Sp. Nueva Ciudad / Ciudad Nueva narrow down the field of possibilities related to the designation, as the toponyms indicate an area where the respective language was or is still spoken. Novgorod could refer to the actual city or the former medieval republic; Villeneuve / Neuville and Neustadt designates more than one locality in the former German and French areas; Nueva Ciudad and Ciudad Nueva are names of districts or neighbourhoods in several cities in Latin America. However, Nueva Ciudad can also be a metaphorical name, without necessarily being the name of a human settlement. Villeneuve and Neuville are names of human settlements, but also anthroponyms, the transition from one onomastic category to the other being a natural phenomenon at a general level. The translation-proper is an option in the case of 'descriptive' proper names, depending on the meaning of the category-related appellative in the denominative collocation. The category-related appellatives with the meaning 'city', 'river,' 'mountain', etc. often form denominative collocations together with an adjective or an opaque proper name. Whenever there is a correspondence between the meaning of the appellative that is part of a denominative collocation (which turns into etymological meaning at the proper name level) and the denominated reality, translation becomes an option. In such cases, one should observe the treatment of fully translatable denominative collocations, as in the examples above, as well as the treatment of partially translatable denominative collocations such as Marea Azov, Munții Carpați, etc.

Building on these reflections, we aim at analysing the translation-proper of toponyms in a few Romanian translations of geographical and historical books from the beginning of the $19^{\text {th }}$ century (see the Bibliography, Sec. Sources; for details regarding the texts, see Gînsac et al., 2017, p. 15 ff.). The term translation-proper designates any type of semantic translation, the only differentiation being between full and partial translation. In this view, we will limit the analysis to the translation of translatable toponyms and the translation of translatable elements within a toponymic collocation, regardless the adopted strategy (literal translation, calque, etc.). Naming the translation strategy is, in fact, a secondary issue, as it only has a classifying role. However, what is truly important is to reveal the circumstances that favour the translation or the non-translation of translatable toponyms and translatable elements within a toponymic collocation. 
Generally, the translation-proper represents a possible option in the case of translatable proper names or partially translatable proper names (i.e. elements within a denominative collocation). We will discuss the translator's options on the translatable toponyms or translatable elements of the toponymic collocations, as well as the introduction of a "traditional norm" by selecting a specific translation solution instead of another. The identification of typical examples where the translatable toponyms or the translatable elements are translated and of the possible motivations for the option to translate a name or an element belonging to a denominative collocation can help establishing some features of the transposition of toponyms in Romanian and providing a series of clues with regard to the motivations of the option to translate or not a translatable toponym or the translatable element(s) of a denominative collocation. The quality and the particularity of the translation are not specific to the translation of proper names but are general translation issues. For this reason, no particular emphasis will be placed on these aspects.

\section{Translations-proper of toponyms in Romanian at the beginning of the $19^{\text {th }} \mathrm{c}$.}

\subsection{Full translations}

The full translation is possible only in the case of composed toponyms or semantically transparent collocations, that is in the case of (quasi)homonymy between the elements of the denominative collocations and the corresponding original appellatives.

In the Romanian texts translated at the end of the $18^{\text {th }}$ century and the beginning of the next, the collocations whose determinant is a geographical term (that indicates the toponymic category), while the determinant is a qualifier or a circumstantial, are generally translated. This corresponds partially to the actual norm, except for the fact that at present toponyms do not preserve the old terminology and no versions are allowed since they are already standardized:

(1) la mer du Nord; la mer du Sud (Dor.fr., p. 266) marea nordului ${ }^{1}$; marea miezii zi (Dor.rom., II, p. $3^{\mathrm{r}}, 3^{\mathrm{v}}$ )

(2) il fiume Negro; lungo lo sponde del Negro (Buf.it., p. 419-420) rîul negru; pe lîngă apa Negrului (Buf.rom., p. 142)

(3) tutto il paese di Terraferma (Buf.it., p. 443) toată țara Pămîntului Întărit (Buf.rom., p. 151)

(4) Terra nuova (Buf. it., p. 438) pămîntul nou (Buf.rom., p. 158)

(5) welche die Salzinsel heist (Cam.germ., p. 176) care se chiamă ostrovul de sare (Cam.rom., p. 112)

(6) les isles du cap Verd (Dor.fr., p. 10) ostroavele Capului Verde (Dor.rom., I, $4^{\mathrm{r}}$ )

(7) bis zu den Inseln des grünen Vorgebirges (Cam.germ., p. 175) pînă la ostrovele Muntelui cel verde (Cam.rom., p. 111)

(8) dem grünen Vorgebirge gegen über (Cam.germ., p. 176) impotriva Muntelui verde (Cam.rom., p. 111)

(9) die Küste de la Orejas (die Obren-Küste) (Cam.germ., p. 230) țărmurile urechilor (Cam.rom., p. 152)

In some other examples (10-11), the entirely transparent denominative collocations whose etymological meaning (of the appellatives with a toponymic function) preserves the implicit denomination relationship of a descriptive type (mainly formed of a determinate and an adjective), as exemplified below, are not translated, but rendered by transliteration or phonetic transcription:

\footnotetext{
${ }^{1}$ All quotations preserve the orthography of the original Cyrillic text, including the use of lowercases for proper names, whenever the case.
} 
(10) il s'avança dans une province, à laquelle il donna le nom de Puerto-viejo (Dor.fr., p. 305) s-au înaintat într-o provinţie, căriia i-au dat nume puerto-veio (Dor. rom., II, p. $31^{\mathrm{v}}$ )

(11) Ces capitainies sont Para, Maranon-Ciaera, Rio-grande, Paraiba, Tamaraca, Fernambuc, Serégipé, Bahia, Ilheos, Spiritu-sancto, Porto-séguro, Rio de Janéiro (Dor.fr., p. 384)

Căpităniile sînt acestea: Para, maranon-chiera, rio-Grande, paraiba, tamaraca, fernambuc, sereghipe, baia, ileos, Spiritu-Sancto, Porto-Securo, rio-deianeiro (Dor.rom., II, p. 88 ${ }^{\text {r }}$ )

Preserving this type of toponyms as close as possible to their original form (through transliteration and phonetic transcription) not only provides clues regarding their area of origin but also denies the possible homonymy with other toponyms belonging to the target language. Debus (2012, p. 51) notes about anthroponyms that, since the identification of the denominated is strictly connected to the original form of the name, the translation could have the contrary effect: “Die Identifikation der Namenträger [author's underlining] ist hier strikt an die originären Formen gebunden, die Übersetzung käme einer volligen Verfremdung gleich". The same scholar states that, although translatable names used to be translated in the past, nowadays they are no longer translated, the latter approach becoming the norm. Regarding the translatable toponyms, it is necessary to differentiate between the toponyms where there exists a correspondence between the etymological meaning of the name and the denominated (i.e., semantically transparent descriptive toponyms) (1-9) and the toponyms where the designation relationship is not based on this correspondence, such as the metaphorical toponyms:Spiritu-sancto, transliterated SpirituSancto, and Rio de Janéiro, rendered by phonetic transcription rio-deianeiro (11), or as in the case below (12):

(12) d'établir une colonie de calviniste à Rio-Janeiro (Dor.fr., p. 384) ca să întemeieză o colonie de calvini la rio-Ianeiro (Dor.rom., II, p. $87^{\mathrm{v}}$ )

The translation of transparent toponyms whose etymological meaning does not correspond to the denominated (i.e. the toponyms whose motivation in the denominative act was not the description of the referent turned into denominated) could easily lead to inferences (etymological, connected first of all to the motivation of the denomination) that do not correspond to the primary function of the proper name, namely identification.

The non-translation of some toponyms that, according to the actual norm, could probably be translated into any language by minimal geographical terminology, is indeed surprising:

(13) zwischen der Nord- und Ostsee (Rum.germ., p. 82)

dintră Nord și Ostsee (Rum.rom., p. 72)

(14) oder bis nach dem Südpol hinlaufe (Cam.germ., p. 13) ori că ajunge pînă la Zidpol (Cam.rom., p. 103).

Translatable toponyms are sometimes translated, sometimes partially translated or replaced by a version from a third language. A relevant example is the toponym Capul Bunei Speranțe [Cape of Hood Hope]:

(15) et dès-lors le cap des Tempêtes reçut le nom de cap de Bonne-espérance (Dor.fr., p. 11) și de atuncea capul tampetii au luat nume de cap de bon esperansu, care va să zică Cap de bună nădejde (Dor.rom., I, p. $4^{\mathrm{v}}$ )

(16) e poi il capo di Buona Speranza (Buf.it., p. 413) apoi capul de bună nădăjduire (Buf.rom., p. 137)

(17) il capo di Buona Speranza (Buf. it., p. 422) capul de buna speranță (Buf.rom., p. 145)

(18) um das Vorgebirge der guten Hoffnung herum (Cam.germ., p. 12) împrejurul munților de Bona Speranza, bunei nădeajde (Cam.rom., p. 9) 
(19) das Vorgebirge der guten Hofnung (Cam.germ., p. 190) muntele bunei nădejdi, Capo de bona Speranza (Cam.rom., p. 123)

This example shows the uncertain approach of proper names as far as translation is concerned. Although translators opt for a more or less accurate translation, the indication of the original name seems to have a role in identifying the denominated. This "free will of the translator", when faced with semantically transparent proper names, suggests that the translation-proper of proper names cannot fulfil the same part as the translation in general of common names.

\subsection{Partial translations}

Partial translation mainly targets partially translatable toponyms, namely the toponymic collocations made of an opaque proper name and an appellative. Partially translatable collocations are formed of either a category-related appellative and a (semantically opaque) proper name or one of its derivates, as in Muntii Carpați [The Carpathian Mountains] or Golful Persic [The Persian Gulf], or of an (opaque) proper name and an adjective (Arabia Felix) or a circumstantial (Indiile de Vest [West Indies], America de Sud [South America]).

Partial translation of transparent toponymic collocations, absent in Romanian today translations, is sometimes an option for the Romanian translators from the $19^{\text {th }}$ century. In the examples $(15-19)$, there occurs the adaptation of Fr. Tempettes in capul tampetii (15), as well as the substitution with a name from a third language, as in munții de Bona Speranza (18) and Capo de bona Speranza (19). The accuracy of the translation (Fr. cap 'promontory' > Rom. munți 'mountains', as in example (6), or the Germ. Vorgebirge 'promontory' > Rom. munte 'mountain', as in examples (7) and (8), sometimes leading to confusions, as in example (46): oțeanul Goronei) represents a matter of translation/ translator rather than an issue regarding the translation of proper names. The translators were most probably aware of the Romanian equivalents of the terms left untranslated in the collocation (17). Yet, they most likely opted for what they thought to be the original proper name of the respective individuality, because that name represented an element with identifying value for the reader.

The non-translation of a translatable element of a toponymic collocation that no longer occurs in our time appears in the $19^{\text {th }}$ century Romanian, as in the examples (20-23) (two examples for each of the toponyms Indiile de Vest [West Indies] and Indiile de Est [East Indies], one for the direct case and one for the oblique case):

(20) Man beschloß daher, einen Mann nach Westindien zu schikken (Cam.germ., p. 166) şi hotărîră a trimite un comiseri la Vest-India (Cam.rom., p. 103)

(21) und daher auch den Nahmen de westindischen Krokodils erhalten hat. (Cam.germ., p. 83) de aceea se și numi Crocodilul Vest Indiei (Cam.rom., p. 47)

(22) ob sie nicht einen Weg zur See bis nach Ostindien finden könten (Cam.germ., p. 11) nu cumva vor afla pre mare vrun drum cătră Ost-India (Cam.rom., p. 9)

(23) welches sich die handlung nach Ostindien zugeeignet hatte (Cam.germ., p. 14) carii numai loruși întrebuința neguțătoria Ost-Indiei (Cam.rom., p. 11)

The non-translation represents the translator's option strictly. This is proved by the explanation provided by the author himself in the same text:

(24) Das eigentliche Indien hingegen, zu welchem man nach Osten hin reisete, ward von dieser Zeit an Ostindien genant (Cam.germ., p. 130)

Și cealaltă India, Ost-India, adecă India răsăritului, căci spre răsărit se află (Cam.rom., p. 76)

(25) so gab man ihnen [...] den Nahmen Westindien, weil man, um von Europa aus dahin zu kommen, gegen Westen fahren muß (Cam.germ., p. 130)

dădu ei nume de Vest-India, adecă India apusului, căci de la Europa a merge într-acolo, cătră apus caută să meargă (Cam.rom., p. 76) 
However, at a general level, the translation of the transparent element is still predominant, be it in the position of determinate (appellative carrying the category-related information) or determinant (adjectival or circumstantial). The geographical terminology, the morphemes and morphological structures specific to the period, the adaptation of borrowed geographical terms (ost, vest, zid, see), along with the ones belonging to the opaque element $(s)$ of the denominative collocation are specific marks of the studied period in such cases. Although our objective is the translation, and not the translator (involving the translator would imply the second level of analysis), the few examples we provide are ordered firstly according to the translated texts and then, whenever possible, with the aim of organizing them on toponymic groups:

(26) cette partie la plus considérable de l'Amérique méridionale (Dor.fr., p. 264) cea mai mare parte a americăi despre miazăzi (Dor.rom., I, p. 2)

(27) dans son livre des nouvelles découvertes dans l'Amérique septentrionale (Dor.fr., p. 407) o carte a sa care să numește noaole Descoperiri a americăi dispre miază noapte (Dor.rom., II, p. $102^{\mathrm{r}}$ )

(28) dans son histoire de l'Amérique septentrionale (Dor.fr., p. 409) in istorie sa pentru america mezii nopți (Dor. rom., II, p. 103 v)

(29) les ridicules opinions des sauvages de l'Amérique septentrionale (Dor.fr., p. 411) vrednicile de rîs socotele a sălbatecilor americăi despre miază noapte (Dor. rom., II, p. 105 ${ }^{\mathrm{r}}$ )

(30) jusqu'au golfe Persique (Dor.fr., p. 12) pănă la boazul persesc [marginal gloss, marked with two parallel horizontal lines on boazul: sinul mării de la persia] (Dor.rom., I, p. $5^{\mathrm{r}}$ )

(31) le golfe persique (Mil.fr., p. 2 [Index of Proper Names]) Golful Persicesc (Mil.rom., p. III [Index of Proper Names])

(32) C'est le golfe de Venise (Mil.fr., p. 1 [Index of Proper Names]) aceasta iaste Golful Veneții, adecă sinul mării al Veneții (Mil.rom., p. I [Index of Proper Names])

(33) dicesi il Golfo di Venezia (Buf. it., p. 449) să chiamă colful de vineție (Buf.rom., p. 168)

(34) nel Golfo Persico (Buf. it., p. 388) în colful persianului (Buf.rom., p. 33)

(35) situata al Mezzodì del Golfo del Messico (Buf.it., p. 434) este despre amiazăzi de colful Mesicu (Buf.rom., p. 152)

(36) die da in dem grossen mexikanischen Meerbusen liegen. (Cam.germ., p. 130) care sînt în Golful de mare México (Cam.rom., p. 77)

Besides the lexical particularities (miazăzi, miază noapte, sîn, boaz) and the morphological ones (-ie, icesc, but also - esc in cases that no longer correspond to the actual norm, as in persesc, or structures reflecting the linguistic norms of the respective period: dispre miază noapte, sinul märii al, Golful de mare), we must notice the influence of the source language in the calques colful de vineție < It. Golfo di Venezia (33) and Golful de mare < Germ. Meerbuse 'gulf' (36).

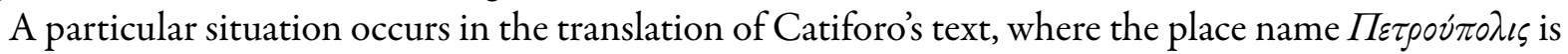
partially translated, as the translator opted for the translation of the transparent element of this compound toponym, dividing thus the structure so as to indicate the etymological under-layer, a possible influence being the etymological explanation included in the text:

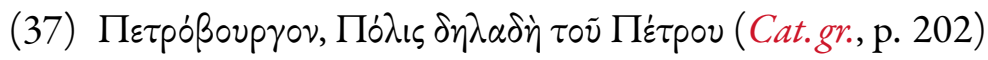

Petru Burgu, adecă cetatea lui Petru (Cat.rom., p. 65 ${ }^{\mathrm{r}}$ )

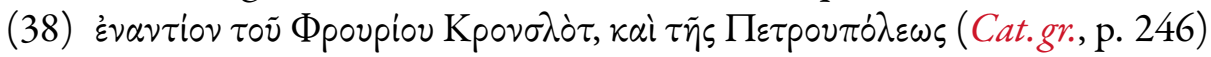
împrotiva cetății Cronslot și a petre burgului (Cat.rom., p. 87v)

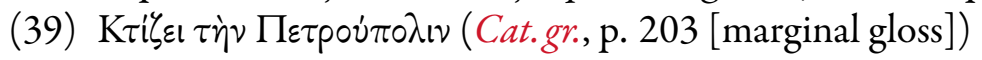
Zideaște Petru Burgul (Cat.rom., p. $65^{\mathrm{r}}$ [marginal gloss, in red]) 


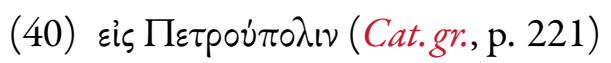
la cetatea lui Petru (Cat.rom., p. $75^{\mathrm{r}}$ )

The 'explanatory' solution alternates with the adaptation of the Greek Petropolis (Cat.rom., p. 74 ), where the German correspondent formally adapted to Greek was adopted, Petruburg (Cat.rom., p. 74 ${ }^{\mathrm{r}}$ ), or an adapted form of the German correspondent, Peterspurg (Cat.rom., p. 96 ${ }^{\mathrm{v}}$ ) < Germ. Petersburg.

Undoubtedly, many partial translations correspond to the present-day norm, except the adaptation of the opaque proper name:

(41) a Levante del fume Gange (Buf. it., p. 391)

despre răsărit de rîul Gangul (Buf.rom., p. 38)

(42) in dem Tejostrome hinauf (Cam.germ., p. 121)

pre rîul Teio în sus (Cam.rom., p. 70)

(43) gegen Morgen den Fluß Indus (Mil.germ., p. 101)

cătră răsărit rîul Indus (Mil.rom., p. 134)

The addition of the term that indicates the onomastic category to facilitate the comprehension is a case of partial translation (44-46). Even if the term does not occur in the source text, the translators often opt for this specification mainly for the less known toponyms:

(44) auf dem Ufer der Wilia (Rum.germ., p. 57)

la țărmurile rîului Vilia (Rum.rom., p. 54)

(45) poi sul Gange (Buf.it., p. 393) asupra rîului Gangul (Buf.rom., 40)

(46) Aquitaine étoit située entre l'Océan, la Garonne \& les Pyrénées (Mil.fr., p. 11) Acvitania, între oțeanul Goronei și între Muntele Pirenei (Mil.rom., p. VII [Index of Proper Names])

The geographical term ocean in "oțeanul Goronei", for "la Garonne" (46) — a river today known both as Fluviul Garonne [The Garonne River] (from Fr. Garonne) and Fluviul Garona [The Garona River] (from Sp. Garona) - is inadequate. This aspect cannot be considered when analyzing the translation of proper names since it relates to the inaccurate understanding of the text rather than to a translation option.

\section{Conclusions}

The research of the translation-proper of toponyms in a period when many foreign place proper names did not have a Romanian equivalent is significant from a double perspective. On the one hand, we identify the semantic functionality of the geographical terms, as well as the differences between the first entries in the Romanian language of certain toponyms (including the oscillation between several translation possibilities) and the modern equivalents. On the other hand, the different translation options displayed by the same translator or by different translators and especially the differences towards the versions that nowadays represent the norm (at the language level, yet not necessarily at an official level) are significant for the theoretical approach of the proper name. These differences explain the lack of functionality of the etymological meaning (the lexical meaning of the etymon) of proper names. The fact that a translation or a formal adaptation of a translatable or partially translatable toponym is imposed in one language is due to tradition to a certain extent, yet the option to translate or not a toponym also depends on the type of toponym (basically toponymic collocations). 


\section{Bibliography}

\section{A. References}

Algeo, J. (1973). On Defining the Proper Name, University of Florida Press, Gainesville.

Ballard, M. (2011 [2001]). Numele proprii în traducere, traducere, cuvînt înainte și note de Georgiana Lungu-Badea, Editura Universității de Vest, Timișoara.

Clarinval, B. (1967). Essai sur le statut linguistique du nom propre, in "Cahiers de lexicologie", 11, p. 29-44, Crossref.

Debus, F. (2012). Namenkunde und Namengeschichte. Eine Einführung, Erich Schmidt Verlag, Berlin.

Gardiner, A. (1957 [1940]). The Theory of Proper Names. A Controversial Essay, Oxford University Press, London.

Gînsac, A.-M. et al. (2017). Practici de traducere a numelor proprii în scrisul românesc premodern (1780-1830), Editura Universității „Alexandru Ioan Cuza”, Iași.

Grass, T. (2002). Quoi! Vous voulez traduire «Goethe»? - Essai sur la traduction des noms propres allemand-français, Peter Lang, Berne.

Hjelmslev, L. (1971). La nature du pronom, in Essais linguistiques, Minuit, Paris, p. 201-207.

Kleiber, G. (1981). Problèmes de référence: descriptions définies et noms propres, Centre d'Analyse Syntaxique, Metz.

Kuryłowicz, J. (1980). The Linguistic Status of Proper Nouns (Names), in “Onomastica”, 25, p. 5-10.

Malblanc (1968 [1944]). Stylistique comparée du français et de l'allemand, Henri Didier, Paris.

Mańczak, W. (1968). Nom propre et nom commun, in "Revue Internationale d'Onomastique”, 20, p. 205-218.

Molino, J. (1982). Le nom propre dans la langue, in "Langages”, 66, p. 5-20, Crossref.

Moya, V. (2001). La traducción de los nombres propios, Cátedra, Madrid.

Vaxelaire, J.L. (2005). Les noms propres. Une analyse lexicologique et historique, Honoré Champion, Paris.

Vaxelaire, J.L. (2006). Pistes pour une nouvelle approche de la traduction automatique des noms propres, in "Meta”, 51 (4), p. 717738, Crossref.

Vinay, J.-P. \& Darbelnet, J. (1958). Stylistique comparée du français et de l’anglais, Didier, Paris.

\section{B. Sources}

Buf. it. = [Claude Buffier], Geografia universale del P<adre $>$ Buffier, Edizione prima Romana aumentata, corretta e ridotta in miglior forma, con un nuovo Trattato della Sfera e d'una Dissertazione sopra l'origine e progresso della Geografia, dal $\mathrm{P}<\mathrm{adre>}$ Francesco Jacquier, in Roma, a spese di Venanzio Monaldini, mercante di Libri, 1775.

Buf.rom. = [Claude Buffier], De obște gheográfie pe limba moldovenească, scoasă de pe Geográfie lui Búfiér după orînduiala care acum mai pre urmă s-au așăzat în Académie de la Parízi, acum întîi tipăită în zilele Prealuminatului și Preaînălțatului Domnului nostru Alexandru Ioan Calimah V<oie>vod, cu blagosloveniia și cu toată cheltuiala Preaosfințitului Mitropolit a toată Moldáviia, Kirío Kir Iácov, întru a Preosfinției sale Tipográfie, s-au tipărit de ierodiacon Gherásim și de Pável Petrov

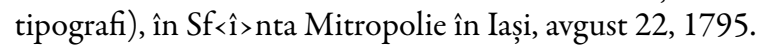

Cam.germ. = [Joachim Heinrich Campe], Kolumbus oder die Entdekkung von Westindien. Ein angenehmes und nützliches Lesebuch für Kinder und junge Leute, von J.H. Campe, mit allerhochst gnädigst Kayserl. Privilegio, Tübingen, bey Wilh. Heinr. Schramm und Joh. Friedr. Balz., 1782.

Cam.rom. = [Joachim Heinrich Campe], Descoperirea Américii. O carte foarte folositoare, alcătuită de Ioánn Háinrih Cámpe, acum întîiu de un iubitoriu de neamul românesc pre românie tălmăcită şi dată afară la lumină, tomul I, cu 4 figuri, cu toată chieltuiala lui Nicóla Nicoláu din Brașov, dată în tipariu la Buda, Crăiasca Tipografie a Universitatei din Péșta, 1816.

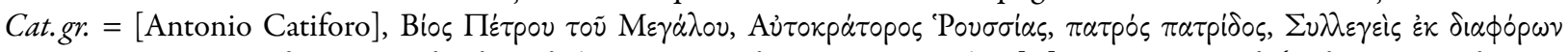

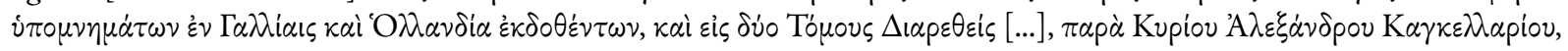

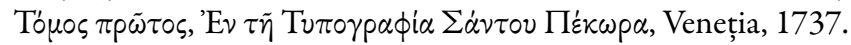

Cat.rom. $=$ [Antonio Catiforo], Istoria ruşilor și viaţa Marelui Petru, monarhul ruşilor, Braşov, traducere efectuată înainte de 1783, copie de Zamfir Marco, din 1788 [în ms. rom. 3161, BAR, p. 1-186].

Dor.fr. = [André Guillaume Contant d'Orville], Histoire des différents peuples du monde, contenant les cérémonies religieuses et civiles, l'origine des religions, leurs Sectes \& Superstitions, \& les Mours \& Usages de chaque Nation, dédiée à monseigneur le Duc de Vrilliere, ministre et secrétaire d'état par M. Contant Dorville, tome cinquième, à Paris, chez Herissant le Fils Libraire, 1771.

Dor. rom. $=$ [André Guillaume Contant d'Orville], Istoría Americăi, cuprinzind un perilipsis a aflării ei, țerimóniile bisericești și politicești [...], acum întîi tălmăcite în dialectul moldovenesc, prin ostineala smeritului Gherasim, arhimandrit Mitropoliei Iașului, Iaşi, tomul I (1800), tomul 2 (1795) [în ms. rom. IV-17, BCU-Iaşi].

Mil.fr. $=$ [Claude François Xavier Millot], Éléments d'histoire générale, première partie: Histoire ancienne, par M. l'Abbé Millot de l'Académie Françoise, \& des Académies de Lyon \& Nancy, tome premier, Nouvelle édition augumentée, à Paris, Chez Durand neveu, 1790.

Mil.germ. $=$ [Claude François Xavier Millot], Des Herrn Abt <Claude > Millot, Mitglieds der Akademie zu Lyon, Universalhistorie alter, mittler und neuer Zeiten, aus dem Französischen, mit den Zusätzen von Wilhelm Ernst Christiani, königlich 
Dänischen wirklichen Justiz - Rath und ordentlichen Professor der Weltweisheit, Beredtsamkeit und Geschichte, wie auch Bibliothekar der königlichen Universität zu Kiel, Erster Band, Bey Franz Haas Buchhändler, Wien, 1794.

Mil.rom. = [Claude Millot], Istorie universală, ádecă de obște, care cuprinde în sine întîmplările veacurilor vechi, întocmită prin signior Mílot, commembru Académii Frîncești din Lyon, iară acum întîia dată tălmăcită în limba românească, tomul I, în Búda s-au tipărit, în Crăiasca Tipografie Orientalicească a Universitatei Péștii, 1800.

Rum.germ. $=$ [Johann Daniel Friedrich Rumpf], Alexander I, Kaiser von Russland. Ein Regierungs-und Karaktergemälde, von I.D.F. Rumpf, Königl. Preuss. expedir. Secretär bei der Abgaben-Direction in Berlin, bei G. Hayn, mit dem Bildniss des Kaisers, 1814.

Rum.rom. = [Johann Daniel Friedrich Rumpf], Arătarea stăpînirei și a caracterului lui Alexándru I, împăratul a toată Róssia, întocmită prin I.D.F. Rumpf, Crăiescul Praisesc a Direcției din Berlin Secretar-Expedítor și Mărirei Sale celui pre dreptate și moștenitoriu Craiu al Borúsiei Frídrih Vílhelm III închinată, iară acum întîiu pre Românie prefăcută și tipărită la Buda, în Crăiasca Tipografie a Universitatei Ungáriei, 1815. 